\title{
La importancia de la radiografía de tórax en el diagnóstico de la neumonía en la COVID-19
}

The value of thorax X-Ray in the diagnosis of COVID-19 pneumonia

\section{CASO}

En diciembre de 2019, se produjo el primer brote de síndrome respiratorio agudo grave causado por el SARS-CoV-2 en China y se extendió por todo el mundo. El 11 de febrero del 2020, la OMS nombró oficialmente la enfermedad como COVID-191. Dado que la mayoría de los pacientes infectados por COVID-19 fueron diagnosticados de neumonía con patrones característicos, los exámenes radiológicos se han vuelto vitales en el diagnóstico temprano y en la evaluación del curso de la enfermedad. Numerosos artículos demuestran la importancia de la TC en el diagnóstico rápido y temprano $0^{2,3}$.

En este artículo, presentamos el caso de un varón de 87 años, dependiente para todas las actividades diarias por antecedentes de demencia, si bien no se conocen otros antecedentes personales. El paciente no tenía antecedentes de exposición o contacto cercano con pacientes confirmados o sospechosos, por lo que la imagen de la placa de tórax y la clínica nos hizo sospechar una infección por coronavirus. El paciente ingresa en el Servicio de Urgencias el 19 de marzo por fallo respiratorio. El cuadro clínico se había iniciado 3 días antes con tos y fiebre.

A su llegada, presentaba disnea y taquipnea. A la exploración destacaba la auscultación pulmonar con roncus dispersos en todos los campos pulmonares.

Los estudios analíticos, que incluyeron hemograma, pruebas de función renal, pruebas de función hepática, búsqueda de antígenos Streptococcus pneumoniae, Legionella pneumophila del grupo 1 y búsqueda del SARSCoV-2, se demostró leucocitosis (22,210/UI), trombocitosis $(646,000 / \mathrm{UI})$, insuficiencia renal con un nivel de creatinina de $6,81 \mathrm{mg} / \mathrm{dL}$ y una PCR de $234,9 \mathrm{mg} / \mathrm{L}$. La búsqueda de SARS-CoV-2 por biología molecular del exudado nasofaríngeo fue positiva.

Se realizó una placa de tórax donde se pudo ver infiltrados difusos bilaterales de características alveolares, pero sin condensaciones definidas, de claro predominio periférico. Sin derrame asociado.

Durante su ingreso, el paciente presentó deterioro progresivo del estado general produciéndose la evolución a muerte en 24 horas, verificándose la sexta muerte por coronavirus en Portugal.

\section{CONCLUSIÓN}

A pesar de ser un paciente con antecedentes epidemiológicos desconocidos, la aparición clínica e imagen típica nos hizo sospechar de COVID-19, lo que nos ha permitido establecer el diagnostico rápido y sencillo sin necesidad de recurrir a la TC. Ante esta sospecha, se pudo aislar al enfermo y optimizar su manejo antes del resultado de la búsqueda del virus. Sin embargo, para la mayoría de los pacientes la placa de tórax es limitada y es necesario recurrir a la TC.

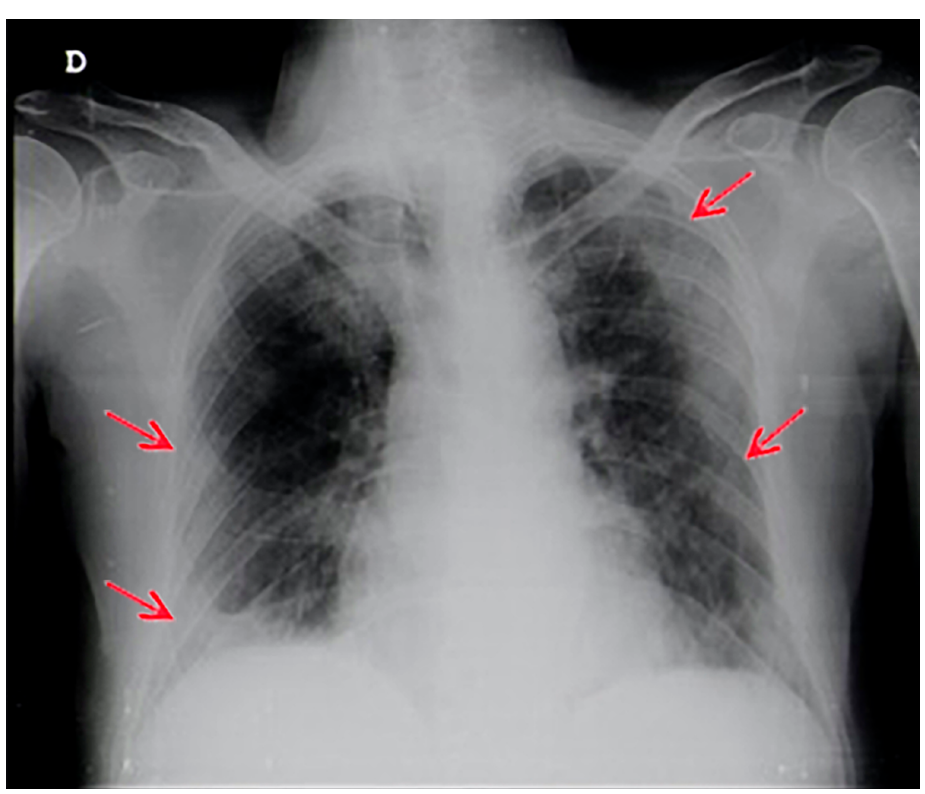

\section{BIBLIOGRAFÍA}

1. Who. Int [Internet]. World Health Organization. c2020 [cited 2020 Apr 22]. Available from: https://www.who.int

2. Li Y, Xia L. Coronavirus Disease 2019 (COVID-19): Role of Chest CT in Diagnosis and Management. AJR Am J Roentgenol. 2020;214(6):1280-1286.

3. Xu X, Yu C, Qu J et al. Imaging and clinical features of patients with 2019 novel coronavirus SARS-CoV-2. Eur J Nucl Med Mol Imaging. 2020;47(5):1275-1280.

Palabras clave: radiografía de tórax, COVID-19, síndrome respiratorio agudo grave. Keywords: thorax X-ray, COVID-19, Severe Acute Respiratory Syndrome.

\section{Carolina Seabra, Vítor Fagundes, Mari Mesquita}

Serviço de Medicina Interna. Centro Hospitalar Tâmega e Sousa, Portugal

Correspondencia: mcarolina.seabra@gmail.com

Cómo citar este artículo: Seabra C, Fagundes V, Mesquita M

La importancia de la radiografía de tórax en el diagnóstico de la neumonía en la COVID-19. Galicia Clin 2021 82-1: 52

Recibido: 23/4/2020; Aceptado: 21/1/2021 // https://doi.org/10.22546/60/2302 